\title{
The Faith of the Righteous According to Habakkuk 2:4b and Rome 1:17
}

\author{
R. F. Bhanu Viktorahadi ${ }^{1) *}$ \\ 1) Faculty of Philosophy, Universitas Katolik Parahyangan Bandung, Indonesia \\ $\left.{ }^{*}\right)$ Correspondent author: torahadi@unpar.ac.id
}

Received: 19 March 2021/ Accepted: 26 September 2021/ Published: 12 October 2021

\begin{abstract}
Habakkuk's prophecy that the righteous will live by his belief (Hab. 2:4a) resonates in Paul's letters, especially the text of Romans 1:17. This paper describes the authentic meaning of the term 'believe' in Habakkuk's prophecy. Furthermore, this accurate meaning gets a more specific articulation in Paul's idea of faith. This paper uses the Historical-Critical method and analyzes the text of Habakkuk 2:4b and the text of Rome 1:17. The correlation between these two texts comes to formulate the faith of the righteous in Christianity, namely credibility, justice, firmness, and faithfulness in carrying out the truth based on love, credibility, justice, firmness, and loyalty to fulfil God's will.
\end{abstract}

Keywords: Habakkuk, Paul, believe, faith, exegetical

Abstrak

Nubuat Habakuk bahwa orang benar akan hidup oleh percayanya (Hab.2:4a) bergaung dalam surat-surat Paulus, terutama teks Rom.l:17. Tulisan ini mendeskripsikan makna otentik istilah 'percaya' dalam nubuat Habakuk. Selanjutnya makna otentik ini memeroleh artikulasi yang lebih spesifik dalam gagasan Paulus tentang iman. Untuk memastikan ketepatan artikulasi itu, tulisan ini menggunakan metode Historis-Kritis dan analisis atas teks Habakuk 2:4b dan teks Rome 1:17. Korelasi antara kedua teks ini sampai pada rumusan iman orang benar dalam kekristenan, yaitu kredibilitas, keadilan, ketegasan, dan kesetiaan dalam melaksanakan kebenaran yang berdasar pada kasih, kredibilitas, keadilan, ketegasan, dan kesetiaan untuk memenuhi kehendak Allah.

Kata-kata kunci: Habakuk, Paulus, percaya, iman, eksegetis

\section{Introduction}

Habakkuk's idea on belief or faith shows his reputation in articulating the law or principles for the believers. Talmud had recorded 
the famous words of Rabbi Simlai (Makkot 23b), "There were 613 mitzvot stated to Moses." However, David had reduced them into ten, and Isaiah into two. Furthermore, Habakkuk had summarized them into just one: 'the righteous shall live by his faith' (Hab. 2:4b)"'. Habakkuk's idea regarding faith found its echo in two of Paul's letters (Rom. 1:17; Gal. 3:11), and in the Epistle to the Hebrews (Hebrews 10:38). In his two verses, Paul replaced the term 'belief' with 'faith.' According to S. L. Johnson Jr., the term 'faith' aligns more with the main purpose of Paul's theological message, which is salvation based on faith. ${ }^{2}$

Although it is not the central theme of Habakkuk's prophecy, ${ }^{3}$ the discussion concerning the faith of the righteous is interesting to pursue further, mainly because it appeared on neotestamentaria tradition. By using Historical-Critical method and text analysis, this paper proposes two research questions. Firstly, how is the authentic meaning of the term 'belief' described in Habakkuk 2:4b? Secondly, how do Paul's verses, particularly Romans 1:17, articulate the term 'belief' into 'faith,' and is the articulation accurate? The discussion and analysis of the two research questions has narrowed down to Habakkuk's idea of the right Christian faith that resonates with Paul's, which are credibility, justice, firmness, and faithfulness in doing the right thing based on love, credibility, justice, firmness, and loyalty to fulfil God's will. These primal values can become a guide for the faithful, especially those who are in a crisis. In times of crisis they must have right thing based on love, credibility, justice, firmness, and loyalty to fulfil God's will.

\section{Method}

To understand the concepts of faith during the time of crisis in the book of Habakkuk, and God's action on that condition, this paper uses Historical-Critical Method, because this methode includes the historical and sociological approach of the text. ${ }^{4}$ This method appeared when a

1 S. M. Lehrman, "Habakkuk," A. Cohen (ed.), in The Twelve Prophets, Soncino Books of the Bibleby (London: Soncino, 1948), 219.

2 S. L. Johnson Jr., "The Gospel That Paul Preached," BSac 128 (1971), 327.

${ }^{3}$ C. L. Feinberg, The Major Messages of the Minor Prophets: Habakkuk, Zephaniah, and Malachi (New York: American Board of Missions to the Jews, 1951), 23.

4 Agus Santoso, "Naskah Kisah Yohanes dan Liturgi Tarian Koptik," Jurnal Jaffray 17, no. 1 (April 2019): 21. 
series of dynamics way of thinking happened in the West during the $17^{\text {th }}$ and $18^{\text {th }}$ centuries. This time period is known as the enlightenment period. ${ }^{5}$ Enlightenment period put intelligence as the only legal instrument that could free man from stupidity and crime. This period is famous for its motto 'I think, therefore I exist' (Je pense donc je suis - cogito ergo sum). ${ }^{6}$ The concept apparently had caused modern society to become arrogant. Dualism, especially between subject and object, was meant to optimize man as the subject who thinks. Therefore, everything around him (the world) could be understood, and eventually mastered later.

This kind of dualism dominated modern society's perspective. Everything outside man was seen as the other objects. ${ }^{7}$ In fact, other men were also often seen as object. Those who felt enlightened considered that ignorance was the only cause of stupidity and crime in society. Optimism towards the power of man's intelligence was supported by the development of science and technology at that time. This development put man as the ruler of nature and history. ${ }^{8}$

New discoveries during the enlightenment period had led to the sense of freedom from the rigidity of religion and the chaos of nature. Those discoveries even helped man to study, master, and utilize both religion and nature for their own interests. This condition made man became autonomous. As an autonomous figure, man felt that he could

${ }^{5}$ Enlightenment is one of the foundation for the birth of medium cevum (Middle Ages). During the era known as 'Modern Ages,' a revolution in philosophy happened. One of the commanders for this revolution was René Descartes. Through radically refusing theological perspectives proposed by Middle Ages thinkers, Descartes designed a research method that could help finding the definite and absolute truth (fundamentum certum et inconcussum veritatis). This idea was written in his two books, Discours de la Methode (1637) and Meditationes de prima Philosophia (1641). The truth that he was pursuing was based on mathematical truth in every knowledge field. Regarding Descartes' ideas and the development of enlightenment era, books that can be read are G. H. R. Parkinson (ed.), Routledge History of Philosophy vol. IV - The Renaissance and Seventeenth Century Rationalism (New York: Routledge, 1999), 167-199.

${ }^{6}$ Descartes, Philosophie von Platon bis Nietzsche. Digitale Bibliothek (Berlin: Directmedia Publishing Gmbh, 1998), 15716.

${ }^{7}$ Anthony C. Thiselton, New Horizons in Hermeneutics. The Theory and Practice of Transforming Biblical Reading (Grand Rapids, Michigan: Zondervan Publishing House, 1992), 318.

${ }^{8}$ Battista Mondin, Os teólogos da libertação (São Paulo: Paulinas, 1980), 14. 
choose and create his own history, free from the constraints of religious norms or the demands of the Bible. Man's autonomous rationality became the driving force that could explain anything. This shifting perspective influenced theological thinking, especially how to understand faith and interpret Biblical texts. Through this perspective, Historical-Critical Method becomes appropriate to make interpretations of Biblical texts according the context of the world's condition and scientific perspective at that time. ${ }^{9}$

In order to understand how this method works, an understanding of the terms used in its nomenclature is needed. The term 'method' means a series of procedure that gives a more objective access to the research's subject. Meanwhile, the term 'historical' suggests the acknowledgement that Biblical texts are arranged and understood in the past. The dynamics happened during that time influenced the texts' meanings, even though it did not rule the possibility for the meanings to also develop throughout times. Lastly, the term 'critical' signifies that Biblical texts are always depending on the creation process, author's identity, composition, their relations to other texts, and their relations to the extra-textual reality (history, politics, and social). ${ }^{10}$ Thus, contextual inquiry completes the work of interpretation. ${ }^{11}$

The choice of using Historical-Critical Method for this research is supported by the fact that the subject of this research is ancient prophetic biblical texts from the Old Testament. Related to the process of transmission and preservation of biblical texts from the Old Testament, it was stated that the texts has been transmitted in the form of manuscript for centuries. Therefore, it is natural that during the long process of transmitting the texts, there are several inaccuracies in writing or quoting in the form of alteration, reduction, or addition to the texts. The texts' instability demands for the effort to read the texts in their authentic forms. Therefore, Historical-Critical Method is very $26-27$.

${ }^{9}$ Martin Volkmann et alii, Método histórico-crítico (São Paulo: CEDI, 1992),

10 Horacio Simian-Yofre, "Diacronia: i metodi storico-critici," Horacio Simian-Yofre, Metodologia dell'Antico Testamento (Bologna: Edizioni Dehoniane Bologna, 2002), 79-80.

"l Selvester Melanton Tacoy, "Analisis Biblika Terhadap Konsep ' $\in \mathrm{V}$

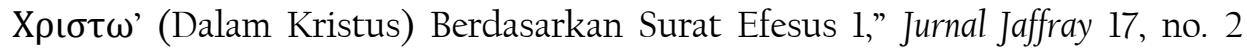
(Oktober 2019): 207. 
helpful in the process of reading and examining the texts in their authentic forms and according to the historical contexts critically. ${ }^{12}$

\section{Result and Discussion}

\section{Prophet and the context of time}

There are only a few information available on Habakkuk's prophecy, as well as accurate biographical information of the prophet himself. The next tradition development among the Jewish in Greek mentions that Habakkuk took part in helping Daniel, who was thrown into lion's den. Habakkuk was flown by an angel to the lion's den in Babel to bring Daniel food. (Tamb. Dan.14:33-39). It remains unknown just who or which tradition created this rather odd legend. From an uncertain etymology, it appears that Habakkuk's name indicates some type of garden plant tree.

Various writers have interpreted and indicated the historical period during which Habakkuk lived differently. Their interpretations revolve around myths brought from generation to generation, as far as an identification of the relationship between 'Chaldeans' (Hab. 1:6) and the Greeks. ${ }^{13}$ It appears that the historical reference concerning the Babylonians (cf. Jer. 22:13-19) as the enemy from the outside, and a Judah king (most probably King Jehoiakim) when handling threats towards internal enemy (Hab. 2:6-12) are more suitable to be used as reliable references. ${ }^{14}$ According to its content, it is presumed that the book was written between the end of $7^{\text {th }}$ centuries and the beginning of $6^{\text {th }}$ centuries, with the historical references being the oppression of Babylonia, which caused unfathomable destruction. This oppression was responded by Habakkuk through threatening the oppressors in a form of prayers and lamentations (Hab. 3-19).

The book's title does not give any information to the readers, neither about Habakkuk's the origin nor his father's name. The living

12 Stephen Pisano, "Il testo dell'Antico Testamento," Horacio SimianYofre, Metodologia dell'Antico Testamento (Bologna: Edizioni Dehoniane Bologna, 2002), 39.

${ }^{13}$ M. Delcor, Essai sur le midrash d'Habacuc (Paris: Edition du Cerf, 1951), 56.

${ }^{14}$ Giovanni Boggio, "I profeti del VII secolo (Naum, Sofonia, Abacuc)," Benito Marconcini e collaboratori, Profeti e Apocalittici (Torino: Editrice Elle Di Ci, 2002), 116. 
period and Habakkuk's activities are also kept in the dark. The effort to trace the time of writing based on the indications of each book also does not give a clear result. By using chronological indications of the books of twelve Minor Prophets, the following result is obtained.

Tabel 1. Indication of Assumed time of writing the Book of Twelve Minor Prophets. ${ }^{15}$

\begin{tabular}{|c|c|c|c|}
\hline Book & Chapter & Chronological indication & $\begin{array}{l}\text { Assumed time } \\
\text { of writing }\end{array}$ \\
\hline Hosea & 14 & $\begin{array}{l}\text { in the days of Uzziah, Jotham, Ahaz, } \\
\text { and Hezekiah, kings of Judah, and in } \\
\text { the days of Jeroboam the son of } \\
\text { Joash, king of Israel. (Hos. l:1) }\end{array}$ & $8 \mathrm{BC}$ \\
\hline Joel & 3 & the day of the Lord & \\
\hline Amos & 9 & $\begin{array}{l}\text { in the days of Uzziah king of } \\
\text { Judah, and in the days of } \\
\text { Jeroboam the son of Joash, king of } \\
\text { Israel. (Am. l:1) } \\
\text { the day of the Lord }\end{array}$ & $8 \mathrm{BC}$ \\
\hline Obadiah & 1 & the day of the Lord & \\
\hline Jonah & 4 & & \\
\hline Micah & 7 & $\begin{array}{l}\text { in the days of Jotham, Ahaz, and } \\
\text { Hezekiah, kings of Judah (Mic. 1:1) }\end{array}$ & $7 \mathrm{BC}$ \\
\hline Nahum & 3 & & \\
\hline Habakkuk & 3 & & \\
\hline Zephaniah & 3 & $\begin{array}{l}\text { in the days of Josiah the son of Amon, } \\
\text { king of Judah (Zeph. 1:l) }\end{array}$ & $6 B C$ \\
\hline Haggai & 2 & $\begin{array}{l}\text { In the second year of Darius the king, } \\
\text { in the sixth month, on the first day } \\
\text { of the month (Hag. l:1) }\end{array}$ & $520 \mathrm{BC}$ \\
\hline Zechariah & 14 & $\begin{array}{l}\text { In the eighth month, in the second } \\
\text { year of Darius (Zech. l:1) }\end{array}$ & $520 \mathrm{BC}$ \\
\hline Malachi & 4 & & \\
\hline
\end{tabular}

The table 1 shows that in the Book of Hebrew, only six books have clear chronological indications. ${ }^{16}$ According to 2 Kings 14:23-27, Jonah the son of Amittai was worked in the days of king Jeroboam II.

15 Patokan dasar pembuatan tabel adalah indikasi kronologi yang terdapat dalam versi Alkitab Ibrani

${ }^{16}$ James D. Nogalski, Literary Precursors of the Book of the Twelve (Berlin: de Gruyter, 1993), 3: Hieronimus said that the texts without chronological data should be read as prophecies which were delivered in the time of lastmentioned king. 
Therefore, Jonah, Hosea, and Amos actually belong to the same period. However, it is possible that the book of Jonah is placed the third after Hosea and Joel-Amos-Obadiah due to the book being the shortest compared to the books of Hosea and Amos. Following the book of Jonah is the book of Micah. Based on the existing indications, prophet Micah worked after king Jeroboam II's period (Mic. 1:1). Next, prophet Nahum preached about the fall of Nineveh (Nah. 1:1), which happened in 612 BC. Therefore, it is chronologically accurate to put the book of Nahum after the book of Micah, who was worked around 7 BC centuries. Meanwhile, prophet Habakkuk prophesied the rise of Babylonia kingdom (Hab. 1:6), which put him after $612 \mathrm{BC}$. Therefore, it is safe to assume that the book of Habakkuk was written after prophet Nahum's period.

The fact that context and background are very unclear is rather puzzling because Habakkuk's presence is very prominent in all parts of the book as the prophet who was wrestled with the dynamic of his age. However, the non-existent information on Habakkuk's context and background can also symbolize that he was a prophet whose figure was able to exceed his historical moments. Habakkuk demonstrates a figure who was able to immerse himself in every historical concerns in his days, while also trying to understand and present God's will in each of those moments. His prophecies were manifested in dialogues between him, as a prophet, and God, which brought lessons for people during his era and future generations. His prophecies were like never ending contemplation, reflection, and prayer. Although short, his prophecies become one of the most insightful prophecies from the Old Testament. ${ }^{17}$.

On the other hand, Habakkuk was a children of time. During his quite long span life-time, the prophet limited himself only to understand, listen, and preach God's Words. Similar to his fellow prophet during that period, Jeremiah, Habakkuk took the initiative by asking to Yahweh, demanding answers, and opening the horizon of hope. His demand on the answer regarding God's justice, as well as God's implicit negligence towards the rise of Babel ${ }^{18}$, unravelled the fact of his period as a prophet, which was around the end of Josiah's period (640-609 sM),

17 L. Alonso Schökel, J. L. Sicre Diaz, Profetas. Comentario II (Madrid: Ediciones Cristiandad, 1987), 1092.

18 Marvin A. Sweeney, The Twelve Prophets. Berit Olam (Collegeville: Liturgical Press, 2000), 455. 
Jehoiakim (609-598 sM), and Jehoiachin (598 sM). ${ }^{19}$ Generally, the experts had agreed upon Habakkuk's period as a prophet. However, there are possibilities that Habakkuk's period as a prophet had already begun during king Manasseh's period (687-642 sM). ${ }^{20}$

\section{Textual Critics}

In general, the experts had agreed on keep using Habakkuk's text in Hebrew as the basis for interpreting, even though the possibilities of reading other texts still exist. ${ }^{21}$ It is indeed acknowledged that Habakkuk's text in Hebrew causes rather difficult textual problem. However, the experts also agreed that when there are doubts on other texts, the Hebrew text is can still be relied upon. ${ }^{22}$ In order for the Hebrew text to still be regarded as reliable, its consonant structure cannot be left out without strong reasoning. ${ }^{23}$ In other words, the consonant structure should be the starting point of discussion during the process of interpreting. ${ }^{24}$

The LAI-LBI Bible translates the Hebrew word $y \bar{a}$ šrāhh as 'righteous.' This translation occurs as the consequence of the first sentence of the verse, which is "Behold, his soul is puffed up; it is not upright within him," (Hab. 2:4a - lō' napešo b $\bar{o}$ '). In the context of this verse, the word 'righteous' becomes the antonym of the phrase 'unrighteous or sinful.' However, according to Victor Morla, this translation is inaccurate. According to Morla, the verse Hab.2:4a has to be understood according to Job's surrenderance. "What is my strength, that I should

19 Gert Prinsloo, "Inner-bibilcal Allusion in Habakkuk's משא (Hab.l:12:20) and Utterances Concerning Babylon in Isaiah 13-23 (Isa 13:1-14:1-10)," OTE 31, no. 3 (2018): 667.

20 Richard D. Patterson, "Habakkuk," Minor Prophets: Hosea-Malachi (Cornerstone Biblical Commentary 10 (Carol Stream, IL: Tyndale, 2008), 397399.

${ }^{21}$ Kei Hiramatsu, "The Structure and Structural Relationships of the Book of Habakkuk," Journal of Biblical Studies 3, no. 2 (Summer 2016): 108.

22 William Hugh Brownlee, The Text of Habakkuk in the Ancient Commentary from Qumran. JBLMS 11 (Philadelphia: Society of Biblical Literature and Exegesis, 1959), 113.

${ }^{23}$ F. F. Bruce, "Habakkuk," Thomas Edward McComiskey (ed.), in the Minor Prophets: an Exegetical and Expository Commentary (Grand Rapids: Baker Book House, 1992), 831-896.

${ }^{24}$ Robert D. Haak, Habakkuk. VTSup 44 (Leiden: Brill, 1992), 1-11. 
wait? And what is my end, that I should be patient?" (Job 6:11). By using the context of Job's surrenderance, the translation should be "those who are impatient in hope." The reason of using Job's context is the theme resemblance of 'God's justice' this text has with Job, Psalm, and Ecclesiastes. $^{25}$

To better understand the previous idea, Morla illustrates Job's surrenderance, yet still full of hope manner using the illustration of a sprinter's effort. ${ }^{26}$

A sprinter who will reach the finish line at the same time with other sprinters should stuck out his neck in such a way in a hope that he/she will be the first who step on the finish line and become the first winner. In the context of the believers, the necks which is stuck out or craned shows the attitude of praying, to watch the sky as the holy places from which the salvation will come from.

From this perspective, "those who are impatient in hope" contradicts "upright man" (Hab. 2:4b). Therefore, there are two contrasting attitudes in facing God's will and plan regarding the future. First, those who are impatient in their hope. Second, those who remain firm in their hope. Those who embody the second attitude show their loyalty towards God and his Words. Habakkuk's book does not actually focus on the identity of 'those who are impatient in their hope' or 'the unrighteous or sinner.' Rather, this book focuses on the question of why evilness still exist. ${ }^{27}$ This strange occurrence causes the effort in clarifying the identity of 'the unrighteous or sinner' remains persistent. ${ }^{28}$

One of the efforts made to clarify the identity of 'the unrighteous or sinner' is finding an alternative reading of the phrase. The alternative reading of the phrase can be found using the Septuagint (LXX). In the Greek version of the bible, the verse Habakkuk 2:4 is as follows:

${ }^{25}$ Michael E. W. Thompson, "Prayer, Oracle and Theophany in the Book of Habakkuk," Tyndale Bulletin 44 (1993): 45-46.

${ }^{26}$ Victor Morla, Comentarios a la Nueva Biblia de Jerusalén: Nahúm, Habacuc, Sofonías (Bilbao: Desclée de Brouwer, 2009), 114.

${ }^{27}$ Jeanette Mathews, Performing Habakkuk: Faithful Re-enactment in the Midst of Crisis (Eugene: Pickwick, 2012), 207.

28 Oskar Dangl, "Habakkuk in Recent Research," Currents in Research: Biblical Studies 9 (2011): 139-144. 


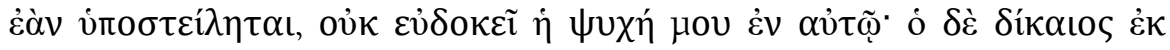

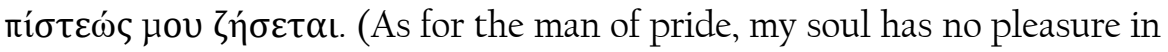
him, but the upright man will have life through his good faith).

The text from the Septuagint identifies the phrase 'the unrighteous or sinner' as 'as for the man of pride, (so that), my soul has no pleasure in him.' In turn, the word 'my soul' and the phrase 'the faith within me,' which emphasize the first-person possessive pronoun in the LXX version of Hab.2:4, offer different alternative meanings. This averts the originally emphasized Judah faith, to faith in God. The Septuagint text highlights God's work more than Judah's doing. Through this interpretation, it is not only the faith of the righteous that will save them. Rather, the one that will save the righteous is God who is faithful. With this understanding, it can be illustrated that when pushing his people to devote, it was as if Habakkuk recalled Abraham's footsteps as the example of a person who is firm in his faith. However, the idea is still one-sided. The interpretation of the Septuagint text completes the idea of being faithful to the promises that God as well as the remaining of Israel would fully participate in fulfilling the agreement between them. ${ }^{29}$

Even though it seems that the alternative reading offered by the Septuagint opens the possibility of God's and the Jews' full participations, another opposite perspective also deserves to be considered. According to Moisés Silva ${ }^{30}$, the incorporation of the firstperson possessive pronoun to the noun ('the faith within me') could be considered as a poor translation of the Hebrew text by the Septuagint. This claim is further supported by the fact that Paul omitted the firstperson possessive pronoun forms the word 'faith' in texts similar to the Septuagint's on Habakkuk 2:4. For example, "The man who does righteousness will be living by his faith" (Rom. 1:17; Gal.3 :11). ${ }^{31}$ By letting go of the possessive pronoun, Paul could bring the readers to the main

29 Uriel Arévalo Mora, "La fe en tiempos de crisis. Acercamiento exegético a Ha 2,4b y su interpretación en el Nuevo Testamento," Reflexiones Teológicas 10 (Julio-Diciembre 2012): 16-17.

30 Moisés Silva, "Old Testament in Paul," Kenneth Pe Ruiter (ed.), in Dictionary of Paul and his Letters (DuPage County: Inter Varsity Press, 1993), 461.

${ }^{31}$ William Hugh Brownlee, The Text of Habakkuk in the Ancient Commentary from Qumran, 44-45. 
purpose of his message, which is salvation based on faith. In other words, Paul wanted to emphasize that God's Faith and the faith of the righteous are inseparable. Karl Barth further confirms this concept in his idea, "For in it there is the revelation of the righteousness of God from faith to faith, The man who does righteousness will be living by his faith." 32

Due to the fact that the word 'faith' holds an important position in the process of interpreting the whole text, a special attention is required. The LAI-LBI Bible translates the Hebrew word emûnāh to 'faith.' This term also has numerous meanings, such as firmness, dependence, loyalty, honesty, and official position. ${ }^{33}$ The context of Habakkuk 2:1-4 explains the meaning of 'faithfulness.' First, God's faith (Hab. 2:1). Second, faith that refers to the vision (Hab. 2:3). Third, the righteous' faith (Hab. 2:4). If a correlation is drawn from the previous context on Habakkuk 1:5 ("Look among the nations, and see; wonder and be astounded. For I am doing a work in your days that you would not believe if told.") as the key to understand Habakkuk 2:4, it is most likely that loyalty implies the loyalty which refers to visions. The reason is because the prophets tend to try to convince the audience that vision will come to those who remain faithful. ${ }^{34}$

The previously mentioned faithfulness also refers to verses from Psalm and the book of Deuteronomy. "Before the Lord, for he comes, for he comes to judge the earth. He will judge the world in righteousness, and the peoples in his faithfulness" (Psalm 96:3). "The Rock, his work is perfect, for all his ways are justice. A God of faithfulness and without iniquity, just and upright is he," (Deut. 32:4). Those two verses are meant to emphasize God's honesty, faithfulness and integrity that contradict human's deviation. In the two verses, deviation is contrasted with honesty, faithfulness and integrity due to the Jews' practical way of thinking. They do not have an expression of faith that is abstractly interpreted. Rather, they always make meanings of the abstract concept through practical and concrete manifestations that can be found and

32 Karl Barth, Carta a los Romanos (Madrid: Biblioteca de Autores Cristianos, 2002), 90.

${ }^{33}$ E. Jenni and C. Westermann, Theological Lexicon of the Old Testament (Peabody, Massachusetts: Hendrickson Publishers, Inc., 1997), 135.

34 Gregory Beale and Donald Arthur (eds.), Commentary on the New Testament Use of the Old Testament (Grand Rapids: Baker Academic, 2007), 608-611. 
experienced in real life. Therefore, to them, faith is a concrete manifestation of justice. ${ }^{35}$ Faith is a form of justice that involves 'the righteous or honest' (șaddiyq) and all aspects of his life, which are family, social-political relation, and belief (faith) to God that ensure the sustainability of his life. In other words, the life of the righteous is guaranteed by God, the Lord of armies. ${ }^{36}$

The term the 'righteous' (saddiyq) appears in two of Habakkuk's lamentations (Hab. 1:1-4.12-17). The two lamentations identify with two different things. The firs lamentation (Hab. 1:1-4) explains that the righteous is not the wicked because the wicked does not have to deal with the law as the moral compass. On the contrary, the second lamentation (Hab.1:12-17) explains that the righteous could once belong amongst the wicked. According to the second lamentation, the righteous is merely those who are a bit wiser than the wicked (Hab.1:13)

Tabel 2. The Structure of Book of Habakkuk. ${ }^{37}$

\begin{tabular}{|c|c|c|c|c|c|}
\hline \multicolumn{4}{|c|}{$\begin{array}{l}\text { 1:1-2:4(5) } \\
\text { Habakkuk's lamentations and God's responses }\end{array}$} & $2: 6-20$ & $3: 1-19$ \\
\hline $1: 2-4$ & $1: 5-11$ & $1: 12-17$ & $2: 1-4$ & Oracle & $\begin{array}{l}\text { Closing } \\
\text { Psalm }\end{array}$ \\
\hline $\begin{array}{l}\text { Lamentation } \\
\quad \text { I }\end{array}$ & $\begin{array}{c}\text { God's } \\
\text { answer I }\end{array}$ & $\begin{array}{l}\text { Lamentation } \\
\quad \text { II }\end{array}$ & $\begin{array}{l}\text { God's } \\
\text { answer II }\end{array}$ & & \\
\hline
\end{tabular}

The second lamentation also accommodates the key text (Hab. 1:5), which mentions 'the nations' as those who will wonder and be astounded. The similar element echoes at the end of the second lamentation (Hab.l:17), which calls 'the nations' as the murder victim of the wicked. In other words, the second lamentation is more inclusive. This inclusivity is shown from the possibilities that the term 'righteous' (saddiyq) does not only refer to the Jews, but can also encompass those

35 Francisco T. Clyde, Introducción al Antiguo Testamento (El Paso: Casa Bautista de Publicaciones, 1999), 189.

36 Debbie Hunn, "Habakkuk 2.4b in its Context: How Far Off Was Paul?," Journal for the Study of the Old Testament 34, no. 2 (2009): 219-239.

37 Brevard S. Childs, Introduction to the Old Testament as Scripture (Philadelphia: Fortress, 1979), 448. 
who abide to the law, or at least wiser than the wicked. ${ }^{38}$ The explanation and interpretation of the term the 'righteous' (saddiyq) in Habakkuk's prophecy becomes the key to interpret the similar term in Paul's Epistles, particularly because Paul refers everybody as the 'righteous,' not only the Jewish. ${ }^{39}$

\section{The correlation between Habakkuk 2:4b and Romans 1:17}

In order to find the correlation between Habakkuk 2:4b and Romans 1:17 as the echo of the prophets in neotestamentaria tradition, a clarification is needed on why Paul omitted the first person possessive pronoun. The previous section has explained that by omitting the possessive pronoun, Paul could bring the readers to the main purpose of his message, which is salvation based on faith. In other words, Paul wanted to emphasize that God's Faith and the faith of the righteous are inseparable. Other than that, the omission of the possessive pronoun is also due to Paul's wish to debate on the justification by faith. "For in it the righteousness of God is revealed from faith for faith, as it is written, 'The righteous shall live by faith,"' (Rom. 1:17).

In that text, Paul interpreted faith as a personal quality that includes credibility, justice, firmness, and faithfulness. According to Paul, that personal quality could not magically appear by itself or stand alone. In other words, faith is not merely human virtue. The virtue has to be found within God's credibility, justice, firmness, and faithfulness that are revealed in the Gospel (Rom. 1:17a). To live as the righteous is to live based on faith found within the Gospel, not merely within the society. ${ }^{40}$

Through the idea that faith is a personal quality that is closely related to the Gospel, Paul aims to correct the understanding of faith that surfaces from the Jewish' synagogue tradition. According to the Torah that is understood by the Jewish, faith is man's effort to gather and accumulate as much merit as possible through various virtuous acts, so that God will reward them a prosperous life. According to Paul, man

38 Francis I. Andersen, Habakkuk: A New Translation with Introduction and Commentary (New York: the Anchor Bible, 2001), 203.

${ }^{39}$ Uriel Arévalo Mora, La fe en tiempos de crisis. Acercamiento exegético a Ha 2,4b y su interpretación en el Nuevo Testamento, 22.

40 Gregory Beale and Donald Arthur (eds.), Commentary on the New Testament Use of the Old Testament, 609. 
cannot demand for God to give him rewards based on the fact that he has done various virtuous acts he claims as faith. Justice is God's right. In other words, God's virtue is justice for those who remains faithful to Him. In Christian perspective, faith is manifested in the belief towards Jesus who suffered, died, and resurrected to redeem man's sin. ${ }^{41}$ This thought appears on Romans 10:4, "For Christ is the end of the law for righteousness to everyone who believes."

Even though Paul's thought pattern is often difficult to understand due to its contradictive nature ${ }^{42}$, his amendment on the Jewish' full religious experience of the Torah needs to be followed so his idea of faith can become clearer. Furthermore, Paul's amendment of the Jewish' synagogue understanding on faith also restores the understanding of the initial meaning of being obidient to Torah which Moses meant as base of faith for the Jewish. God gives the book of Torah to the Jewish through Moses to ethically rule the relation between Himself and the Jewish, as well as the relation among the Jewish themselves. The book of Torah also become the separating sign between the Jewish and their neighbors. However, in reality, the Jewish understood the Torah as a chance for them to justify and legalize their behavior on their own strength to win over fake comfort in front of God. Paul reveals this wrong understanding in Rom.10:3, "For, being ignorant of the righteousness of God, and seeking to establish their own, they did not submit to God's righteousness."

This wrong understanding put the Torah not as the Divine norm to erase sin or as a law that separates the Jewish from other nations' custom. The wrong understanding also strips law from God's intention so the Israelites fully participate in His justice. Although acknowledging the difficulties in differentiating the right and the wrong related to full religious experience on sinagogal Torah, Paul affirms that the reason of having faith to God by following Torah was not arrogance, instead the faith of of righteous on truth within God and Christ. Paul further emphasizes the idea in his discourse to the people in Philippians regarding the true righteousness.

${ }^{41}$ Wolfgang Trilling, El Nuevo Testamento y su mensaje (Barcelona: Herder, 1980), 45 .

${ }^{42}$ George Eldon Ladd, Teología del Nuevo Testamento (Bogotá: Clie, 2002), 656. 
But whatever gain I had, I counted as loss for the sake of Christ. Indeed, I count everything as loss because of the surpassing worth of knowing Christ Jesus my Lord. For his sake I have suffered the loss of all things and count them as rubbish, in order that I may gain Christ and be found in him, not having a righteousness of my own that comes from the law, but that which comes through faith in Christ, the righteousness from God that depends on faith, (Phil.3:7-9).

Paul does not base his understanding of the life of the faithful merely on longer days or abundant possessions. Rather, Paul sees that the true faith as in the way of righteousness there is life (Ams.12:28; 11:19; 10:16). Only through credibility, justice, firmness, and faithfulness to God's wills and promises, 'the upright man will have life' (Hab.2:4b). In this context, living does not only mean physical survival during time of crisis, but also a righteous relationship with God. ${ }^{43}$

\section{Implication}

Following Habakkuk's understanding that is echoed in Paul's Epistles, particularly in Rom.l:17, faith is credibility, justice, firmness and faithfulness in being righteous according to God's will. True faith is not only made out of man's effort. Rather, true faith is man's dynamics to align his virtue with God's will that is revealed in the Gospel and through Jesus Christ. Therefore, the righteous faith is not instantly exchangeable in nature, but someone has to be earnest and faithful in harmonizing his or her will with God's will as it is not something that can easily and effortlessly be obtained, but scarce and valuable to be fight for. $^{44}$

The righteous faith is the faith which is earnestly faithfully preserved eventhough in crisis period as expressed by Habakkuk to be the life fulfilment of the faithful. ${ }^{45}$

Though the fig tree should not blossom, nor fruit be on the vines, the produce of the olive fail and the fields yield no food, the flock be cut off

${ }^{43}$ D. Hill, Greek. Words and Hebrew Meanings: Studies in the Semantics of SoterioLogical Terms. SNTSMS 5 (Cambridge: Cambridge University Press, 1967), 165.

44 Dietrich Bonhöeffer, El precio de la gracia (Salamanca: Sígueme, 2004), $15-26$.

45 D. E. Gowan, The Triumph of Faith in Habakkuk (Atlanta: John Knox, 1976), 42-43. 
from the fold and there be no herd in the stalls, yet I will rejoice in the Lord; I will take joy in the God of my salvation. God, the Lord, is my strength; he makes my feet like the deer's; he makes me tread on my high places, (Hab. 3:17-19).

The understanding of the faith of the righteous according to Habakkuk and Paul's Letter to the Romans gives spiritual implications for the appreciation of the faith of Christians who want to become righteous man. This understanding emphasizes that faith is not enough just to believe in the meaning of surrender. For the righteous man, faith is a process to survive in a crisis, as well as persevere in love, credibility, justice, firmness, and loyalty to fulfil God's will.

\section{Conclusion}

The right conception of faith in the time of crisis according to Habakkuk and Paul contradicts with several other conceptions which stem from the idea of prosperity. Those conceptions tend to measure the truth of faith based on materialistic prosperity, health, and other earthly matters. These kinds of conceptions are ethically wrong because they treat God merely as a bucket full of blessings who is able to continuously give blessings with the effort of caring and preserving. In fact, more than anything, the righteous faith is the one that put continuous effort in believing in God, "...the produce of the olive fail and the fields yield no food..." (Hab.3:17), because "but godliness with contentment is great gain" (1Tim.6:6). Therefore, the righteous Christian faith according to Habakkuk that is echoed by Paul is credibility, justice, firmness, and faithfulness in doing the right thing based on compassion, credibility, justice, firmness, and faithfulness in order to fulfil God's will.

\section{Bibliography}

Andersen, Francis I. Habakkuk: A New Translation with Introduction and Commentary. New York: the Anchor Bible, 2001.

Barth, Karl. Carta a los Romanos. Madrid: Biblioteca de Autores Cristianos, 2002.

Beale, Gregory and Donald Arthur (eds.). Commentary on the New Testament Use of the Old Testament. Grand Rapids: Baker Academic, 2007. 
Boggio, Giovanni. "I profeti del VII secolo (Naum, Sofonia, Abacuc)." Benito Marconcini e collaboratori. Profeti e Apocalittici. Torino: Editrice Elle Di Ci, 2002.

Bonhöeffer, Dietrich. El precio de la gracia. Salamanca: Sígueme, 2004.

Brownlee, William Hugh. The Text of Habakkuk in the Ancient Commentary from Qumran. JBLMS 11. Philadelphia: Society of Biblical Literature and Exegesis, 1959.

Bruce, F. F. "Habakkuk." Thomas Edward McComiskey (ed.). In The Minor Prophets: an Exegetical and Expository Commentary. Grand Rapids: Baker Book House, 1992.

Childs, Brevard S. Introduction to the Old Testament as Scripture. Philadelphia: Fortress, 1979.

Clyde, Francisco T. Introducción al Antiguo Testamento. El Paso: Casa Bautista de Publicaciones, 1999.

Dangl, Oskar. "Habakkuk in Recent Research." Currents in Research: Biblical Studies 9, 2011: 131-168.

Delcor, M. Essai sur le midrash d'Habacuc. Paris: Edition du Cerf, 1951.

Descartes, Philosophie von Platon bis Nietzsche. Digitale Bibliothek. Berlin: Directmedia Publishing Gmbh, 1998.

Feinberg, C. L. The Major Messages of the Minor Prophets: Habakkuk, Zephaniah, and Malachi. New York: American Board of Missions to the Jews, 1951.

Gowan, D. E. The Triumph of Faith in Habakkuk. Atlanta: John Knox, 1976.

Haak, Robert D. Habakkuk.VTSup 44. Leiden: Brill, 1992.

Hill, D. Greek. Words and Hebrew Meanings: Studies in the Semantics of SoterioLogical Terms. SNTSMS 5. Cambridge: Cambridge University Press, 1967.

Hiramatsu, Kei. "The Structure and Structural Relationships of the Book of Habakkuk." the Journal of Biblical Studies 3, no. 2 (Summer 2016): 106-129.

Hunn, Debbie. Habakkuk 2.4b in its Context: How Far Off Was Paul?" Journal for the Study of the Old Testament 34, no. 2 (2009): 219-239.

Jenni, E.and Westermann, C. Theological Lexicon of the Old Testament. Peabody, Massachusetts: Hendrickson Publishers, Inc., 1997.

Johnson Jr., S. L. “The Gospel That Paul Preached," BSac 128, 1971.

Ladd, George Eldon. Teología del Nuevo Testamento. Bogotá: Clie, 2002.

Lehrman, S. M. "Habakkuk," A. Cohen (ed.). In The Twelve Prophets, Soncino Books of the Bibleby. London: Soncino, 1948.

Mathews, Jeanette. Performing Habakkuk: Faithful Re-enactment in the Midst of Crisis. Eugene: Pickwick, 2012.

Mondin, Battista. Os teólogos da libertação. São Paulo: Paulinas, 1980. 
Mora, Uriel Arévalo. "La fe en tiempos de crisis. Acercamiento exegético a Ha 2,4b y su interpretación en el Nuevo Testamento." Reflexiones Teológicas 10 (Julio-Diciembre 2012): 11-36.

Morla, Victor. Comentarios a la Nueva Biblia de Jerusalén: Nahúm, Habacuc, Sofonías. Bilbao: Desclée de Brouwer, 2009.

Nogalski, James D. Literary Precursors of the Book of the Twelve. Berlin: de Gruyter, 1993.

Parkinson, G. H. R. (ed.). Routledge History of Philosophy vol.IV - The Renaissance and Seventeenth Century Rationalism. New York: Routledge, 1999.

Patterson, Richard D. "Habakkuk." Minor Prophets: Hosea-Malachi. Cornerstone Biblical Commentary 10. Caalrol Stream, IL: Tyndale, 2008.

Pisano, Stephen. "Il testo dell'Antico Testamento." Horacio Simian-Yofre. Metodologia dell'Antico Testamento. Bologna: Edizioni Dehoniane Bologna, 2002.

Prinsloo, Gert. "Inner-bibilcal Allusion in Habakkuk's משא (Hab.l:1-2:20) and Utterances Concerning Babylon in Isaiah 13-23 (Isa 13:1-14:110)." OTE 31, no. 3 (2018): 663-69l.

Santoso, Agus. "Naskah Kisah Yohanes dan Liturgi Tarian Koptik." Jurnal Jaffray 17, no. 1 (April 2019): 19-34.

Schökel, L. Alonso, J. L. Sicre Diaz. Profetas. Comentario II. Madrid: Ediciones Cristiandad, 1987.

Silva, Moisés. "Old Testament in Paul." Kenneth Pe Ruiter (ed.). In Dictionary of Paul and his Letters. DuPage County: Inter Varsity Press, 1993.

Simian-Yofre, Horacio. "Diacronia: i metodi storico-critici." Horacio Simian-Yofre. Metodologia dell'Antico Testamento. Bologna: Edizioni Dehoniane Bologna, 2002.

Sweeney, Marvin A. The Twelve Prophets. Berit Olam. Collegeville: Liturgical Press, 2000.

Tacoy, Selvester Melanton. "Analisis Biblika Terhadap Konsep ' $\in \mathrm{v}$ X 17, no. 2 (Oktober 2019): 203-222.

Thiselton, Anthony C. New Horizons in Hermeneutics. New Horizons in Hermeneutics. The Theory and Practice of Transforming Biblical Reading. Grand Rapids, Michigan: Zondervan Publishing House, 1992.

Thompson, Michael E. W. "Prayer, Oracle and Theophany in the Book of Habakkuk." Tyndale Bulletin 44, 1993: 33-53.

Trilling, Wolfgang. El Nuevo Testamento y su mensaje. Barcelona: Herder, 1980.

Volkmann, Martin et alii. Método Histórico-Crítico. São Paulo: CEDI, 1992. 